ORIGINAL ARTICLE

\title{
Public trust in health care: the system or the doctor?
}

\author{
M W Calnan, E Sanford
}

See editorial commentary, p 88

Qual Saf Health Care 2004;13:92-97. doi: 10.1136/qshc.2003.009001

Objectives: To examine how the public assess trust in health care in England and Wales.

Design: Postal structured questionnaire in cross sectional survey.

Setting: Random sample of people on the electoral register in England and Wales.

See end of article for authors' affiliations Subjects: People aged 18 and over.

Main outcome measures: General levels of trust and confidence in health care.

Results: The response rate was $48 \%(n=1187)$. The mean level of confidence (trust) in the healthcare .....................

Correspondence to: Professor M W Calnan, Department of Social Medicine, Canynge Hall, Whiteladies Road, University of Bristol, Bristol BS8 2PR, UK:

m.w.calnan@bristol.ac.uk system was 6.0 out of a score of 10. Levels of distrust appeared relatively high with at least 356 (30\%) respondents reporting little or very little trust for 28 of 32 specific aspects of health care. The highest levels of distrust were found in relation to how the health service was run and financed, particularly waiting times and the implication of cost cutting for patients. Statistical analysis by univariable linear regression of the specific determinants of generic assessments of public trust (confidence) suggested that the key aspects were patient centred care and levels of professional expertise. Being covered by private health insurance was also a key determinant of levels of public trust.

Conclusion: Public assessment of trust tends to address the views of care at the micro level. Policy makers

Accepted for publication 16 January 2004 concerned with the erosion of public trust need to target aspects associated with patient centred care and professional expertise.

$\mathrm{P}$ ublic trust in health care in the UK is believed to have been shaken by the recent intense media scrutiny about scandals over medical competence such as the enquiry into paediatric cardiac surgery in Bristol, the conviction of the GP Harold Shipman, and the removal of organs from children at Alder Hey Hospital. This has led to policies aimed at creating more effective accountability for healthcare professionals. ${ }^{1-3}$ However, the erosion of public trust in health care has also been linked with how the NHS is run and financed (box 1) and the increasing pressure on NHS budgets due to increased demand by an ageing population, the rising costs of technology, and increases in public sector pay. ${ }^{4}$ Others have suggested that it might be associated with changes in public attitudes, values, and expectations of health professionals brought about by wider social and cultural changes such as the overall decline in deference to authority and trust in experts and institutions and increasing reliance on personal judgements of risk, ${ }^{5-7}$ or the overall decline in social trust due to the breakdown in communities, social networks, and cohesion. ${ }^{8}$

Definitions of trust vary but, as Davies ${ }^{9}$ argues, "all embody the notion of expectations: expectations by the public that healthcare providers will demonstrate knowledge, skill and competence; further expectations too that they will behave as true agents (that is, in the patients best interest) and with beneficence, fairness and integrity. It is these collective expectations that form the basis of trust" (page 193).

The empirical evidence about the extent of the decline in trust in health care appears to be limited and inconsistent. In Europe there is evidence of a decline in trust but this is claimed to vary according to the values and organisational principles of the country's healthcare system. ${ }^{10}{ }^{11}$ In the USA public trust in health care is believed to have gradually declined during the past 20 years $^{12}{ }^{13}$ and, over a similar period, there is evidence of a pattern of decline in public satisfaction (not necessarily trust) with the NHS in the UK. ${ }^{14}{ }^{15}$ However, while trust in health care may be in decline, trust in medical practitioners in the UK seems still to be strong, at least compared with other professional occupations. ${ }^{16}$
According to recent survey evidence, ${ }^{16}$ trust in the medical profession has risen steadily over the last decade.

This apparent inconsistency in the pattern of evidence raises the question about how the public assesses trust in health care in the UK. Is the public's assessment based on criteria associated with the structure, organisation, and financing of the health service or is it more to do with "micro" level issues such as the quality of health care provision, professional expertise, and the doctor-patient relationship? This question is the focus of this study which presents evidence on levels of trust and explores more critically the specific determinants of public trust.

\section{METHOD}

\section{Sampling}

The analysis was based on data collected between October 2002 and February 2003 in a postal questionnaire sent to a random sample of 2777 people aged 18 and over in England and Wales on the 2000 electoral register (that is, registered to vote in local and national elections). The sampling methodology adopted used an equal probability design. Addresses were stratified by region and within region by local authority.

\section{Questionnaire development}

This survey formed part of an international study comparing levels of trust in the UK with those in Germany and the Netherlands. Common core questions were therefore necessary and these were derived from a survey instrument developed in the Netherlands, the specific items of which were based on themes which emerged from qualitative research. ${ }^{10}$ The questions used in the survey are shown in Appendix 1 available online on the QSHC website (www.qshc.com/supplemental). Confidence was used as an equivalent of trust primarily because, in the Netherlands and Germany, no semantic distinction is made between the terms. These questions were piloted $(n=50)$ and tailored to the context of the NHS where appropriate.

No information is available on the reliability and validity of the general question (overall confidence in today's healthcare 
Box 1 National Health Service (NHS) in England and Wales

- National system financed primarily through public taxation and free at point of access.

- Majority of public are registered with a general practitioner (family doctor) who acts as their first point of contact with the NHS.

- General practitioners and primary healthcare teams aim to act as coordinators of health and social care for their patients and as "gate keepers" to hospital and secondary specialist services.

- There is a relatively small private health sector which is primarily accessible to the minority $(20 \%)$ covered by private health insurance.

system). However, 30 of the 32 specific items of trust were derived from the Dutch instrument. ${ }^{10}$ These items were categorised into six dimensions on the basis of evidence from a factor analysis of the Dutch data as follows: (A) patient centred focus; (B) macro level policies; (C) professional expertise; (D) quality of care; (E) communication and provision of information; and (F) quality of cooperation.
Two further items related to the recent NHS context-the decline in deference to doctors ("patients show doctors respect") and concern about the regulation and accountability of doctors ("doctors are well regulated in this country")—were also added.

\section{Statistical analysis}

The statistical analyses were carried out using Stata software, version 8. Descriptive statistics are presented about the level of trust and confidence in different healthcare practitioners and with specific aspects of health care and the healthcare system as a whole. Univariable linear regression analysis examined the specific aspects of trust which were most strongly associated with a general measure of trust. The general measure was derived from the question: "How much confidence do you have in today's healthcare system?" Subjects were asked to give a rating between 1 (not at all confident) and 10 (extremely confident). ${ }^{1} 1157$ answered the question giving a mean (SD) score of 6.0 (2.0). As the specific aspects of trust are coded in an ordinal fashion, linearity of these variables within the regression models was checked using the Wald test. There was no reason to suspect nonlinearity and these variables were used as though continuous within these models. Also presented are regression analyses, both univariable and multivariable, of sociodemographic variables on the overall rating of trust.

Table 1 Levels of trust in specific aspects of health care

\begin{tabular}{|c|c|c|}
\hline Category of care & Number & Little/very little trust \\
\hline \multicolumn{3}{|l|}{ (A) Patient focused care } \\
\hline Patients are taken seriously & 1140 & $32 \%$ \\
\hline Patients get enough attention & 1140 & $37 \%$ \\
\hline Doctors provide their patients with good guidance & 1137 & $32 \%$ \\
\hline Patients are listened to & 1145 & $45 \%$ \\
\hline $\begin{array}{l}\text { Doctors spend enough time on their patients } \\
\text { (B) Macro level policies and patient care }\end{array}$ & 1138 & $63 \%$ \\
\hline $\begin{array}{l}\text { Medical help and patient care will not be compromised by the } \\
\text { shortening of waiting lists }\end{array}$ & 1137 & $62 \%$ \\
\hline Patients won't be the victim of rising costs of health care & 1134 & $70 \%$ \\
\hline Waiting times are never too long & 1137 & $75 \%$ \\
\hline Cost cutting does not disadvantage patients & 1135 & $68 \%$ \\
\hline $\begin{array}{l}\text { Patients will be able to pay for their own health care if they have to } \\
\text { (C) Professional expertise }\end{array}$ & 1128 & $65 \%$ \\
\hline New treatments are put into practice in the healthcare system & 1137 & $45 \%$ \\
\hline $\begin{array}{l}\text { The education and training of doctors in this country is one of the } \\
\text { world's best }\end{array}$ & 1140 & $17 \%$ \\
\hline Doctors can do everything & 1132 & $65 \%$ \\
\hline $\begin{array}{l}\text { Doctors know everything about all sorts of diseases } \\
\text { (D) Quality of care }\end{array}$ & 1139 & $65 \%$ \\
\hline Patients will always get the best treatment & 1141 & $50 \%$ \\
\hline Doctors always make the right diagnosis & 1144 & $31 \%$ \\
\hline Patients are referred in time & 1134 & $45 \%$ \\
\hline Patients always get the right dose of medicine & 1142 & $34 \%$ \\
\hline Patients always get the right medicine & 1143 & $43 \%$ \\
\hline $\begin{array}{l}\text { A lot of care is taken to keep patients' medical information } \\
\text { confidential in the health service }\end{array}$ & 1143 & $17 \%$ \\
\hline Doctors always do enough tests & 1141 & $46 \%$ \\
\hline \multicolumn{3}{|l|}{ (E) Communication and provision of information } \\
\hline The information given to patients is clear and understandable & 1137 & $40 \%$ \\
\hline Patients get sufficient information about the cause of their problems & 1134 & $44 \%$ \\
\hline Doctors discuss things fully with their patients & 1140 & $44 \%$ \\
\hline $\begin{array}{l}\text { Patients get sufficient information about the various treatments that } \\
\text { are available }\end{array}$ & 1142 & $62 \%$ \\
\hline $\begin{array}{l}\text { Patients get sufficient information about the effects of their treatment } \\
\text { (F) Quality of cooperation }\end{array}$ & 1139 & $54 \%$ \\
\hline Healthcare providers are good at cooperating with each other & 1136 & $47 \%$ \\
\hline Patients are not given conflicting information & 1140 & $52 \%$ \\
\hline $\begin{array}{l}\text { High levels of specialisation do not cause problems in the healthcare } \\
\text { system }\end{array}$ & 1129 & $38 \%$ \\
\hline \multicolumn{3}{|l|}{ New items } \\
\hline Doctors are well regulated in this country & 1139 & $28 \%$ \\
\hline Patients will show doctors respect & 1143 & $19 \%$ \\
\hline
\end{tabular}


Table 2 Specific determinants of overall rating of trust/confidence (rank order)

\begin{tabular}{|c|c|c|c|c|c|c|}
\hline Rank order & Individual determinants & Number & Mean change* & $95 \% \mathrm{Cl}$ & $p$ value & $R^{2}$ \\
\hline 1 & (A) Patients are taken seriously & 1140 & -0.801 & $(-0.89$ to -0.71$)$ & 0.00 & 0.21 \\
\hline 2 & (A) Patients get enough attention & 1140 & -0.742 & $(-0.82$ to -0.66$)$ & 0.00 & 0.21 \\
\hline 3 & (D) Patients will always get the best treatment & 1141 & -0.703 & $(-0.78$ to -0.62$)$ & 0.00 & 0.21 \\
\hline 4 & (D) Doctors always make the right diagnosis & 1144 & -0.687 & $(-0.78$ to -0.59$)$ & 0.00 & 0.16 \\
\hline 5 & (A) Doctors provide their patients with good guidance & 1137 & -0.651 & $(-0.74$ to -0.56$)$ & 0.00 & 0.15 \\
\hline 6 & (F) Healthcare providers are good at cooperating with each other & 1136 & -0.635 & $(-0.72$ to -0.55$)$ & 0.00 & 0.15 \\
\hline 7 & (C) New treatments are put into practice in the healthcare system & 1137 & -0.622 & $(-0.71$ to -0.53$)$ & 0.00 & 0.14 \\
\hline 8 & (E) The information given to patients is clear and understandable & 1137 & -0.618 & $(-0.70$ to -0.53$)$ & 0.00 & 0.15 \\
\hline 9 & (A) Patients are listened to & 1145 & -0.611 & $(-0.69$ to -0.53$)$ & 0.00 & 0.16 \\
\hline 10 & (A) Doctors spend enough time on their patient & 1138 & -0.605 & $(-0.69$ to -0.52$)$ & 0.00 & 0.15 \\
\hline 11 & (E) Patients get sufficient information about the cause of their problem & 1136 & -0.600 & $(-0.68$ to -0.51$)$ & 0.00 & 0.14 \\
\hline 12 & (D) Patients are referred in time & 1134 & -0.593 & $(-0.68$ to -0.51$)$ & 0.00 & 0.15 \\
\hline 13 & $\begin{array}{l}\text { (B) Medical help and patient care will not be compromised by the } \\
\text { shortening of waiting lists }\end{array}$ & 1137 & -0.592 & $(-0.68$ to -0.50$)$ & 0.00 & 0.12 \\
\hline 14 & (E) Doctors discuss things fully with their patients & 1140 & -0.590 & $(-0.67$ to -0.51$)$ & 0.00 & 0.15 \\
\hline 15 & (D) Patients always get the right dose of their medicine & 1142 & -0.588 & $(-0.68$ to -0.50$)$ & 0.00 & 0.13 \\
\hline 16 & $\begin{array}{l}\text { (C) The education and training of doctors in this country is one of the } \\
\text { world's best }\end{array}$ & 1140 & -0.581 & $(-0.67$ to -0.49$)$ & 0.00 & 0.12 \\
\hline 17 & $\begin{array}{l}\text { (E) Patients get sufficient information about the various treatments } \\
\text { that are available }\end{array}$ & 1142 & -0.571 & $(-0.66$ to -0.49$)$ & 0.00 & 0.14 \\
\hline 18 & (D) Patients always get the right medicine & 1143 & -0.570 & $(-0.66$ to -0.48$)$ & 0.00 & 0.12 \\
\hline 19 & $\begin{array}{l}\text { (D) A lot of care is taken to keep patients' medical information } \\
\text { confidential in the health service }\end{array}$ & 1143 & -0.566 & $(-0.67$ to -0.47$)$ & 0.00 & 0.10 \\
\hline 20 & (E) Patients get sufficient information about the effects of their treatments & 1139 & -0.560 & $(-0.64$ to -0.48$)$ & 0.00 & 0.14 \\
\hline 21 & Doctors are well regulated in this country & 1139 & -0.558 & $(-0.65$ to -0.46$)$ & 0.00 & 0.11 \\
\hline 22 & (B) Patients won't be the victims of rising costs of health care & 1134 & -0.536 & $(-0.62$ to -0.45$)$ & 0.00 & 0.10 \\
\hline 23 & (C) Doctors can do everything & 1132 & -0.524 & $(-0.62$ to -0.43$)$ & 0.00 & 0.11 \\
\hline 24 & (D) Doctors always do enough tests & 1141 & -0.516 & $(-0.60$ to -0.43$)$ & 0.00 & 0.11 \\
\hline 25 & (C) Doctors know everything about all sorts of diseases & 1139 & -0.480 & $(-0.57$ to -0.39$)$ & 0.00 & 0.09 \\
\hline 26 & (D) Doctors don't prescribe medicines too late & 1132 & -0.452 & $(-0.55$ to -0.35$)$ & 0.00 & 0.07 \\
\hline 27 & (F) Patients aren't given conflicting information & 1140 & -0.383 & $(-0.48$ to -0.29$)$ & 0.00 & 0.05 \\
\hline 28 & Patients will show doctors respect & 1143 & -0.376 & $(-0.48$ to -0.27$)$ & 0.00 & 0.04 \\
\hline 29 & (B) Waiting times are never too long & 1137 & -0.358 & $(-0.45$ to -0.27$)$ & 0.00 & 0.05 \\
\hline 30 & (B) Cost cutting does not disadvantage patients & 1135 & -0.343 & $(-0.43$ to -0.26$)$ & 0.00 & 0.05 \\
\hline 31 & $\begin{array}{l}\text { (F) High levels of specialisation do not cause problems in the healthcare } \\
\text { system }\end{array}$ & 1129 & -0.278 & $(-0.38$ to -0.18$)$ & 0.00 & 0.02 \\
\hline 32 & (B) Patients will be able to pay for their own health care if they have to & 1128 & -0.081 & $(-0.18$ to -0.15$)$ & 0.10 & 0.01 \\
\hline
\end{tabular}

\section{RESULTS}

\section{Response rate and sample representativeness}

Respondents were sent three follow up mailings in addition to the first mailing. The original sample of 2777 was reduced to 2489 as 288 had died or moved away. 1187 (48\%) completed the questionnaire, $75(3 \%)$ refused, and 1227 (49\%) did not reply.

The background characteristics (age, sex, marital status, socioeconomic status, health status, and limiting longstanding illness) of the sample were compared with those of the adult $(18+)$ population ${ }^{17}$ as no information was available on non-respondents. There were significantly lower proportions of men $(\mathrm{p}<0.001)$ and respondents in the $15-24$ and $25-34$ age groups $(\mathrm{p}<0.001)$ in the survey population than in the background population, but higher proportions in the older age group $(45+)(p<0.001)$. There were significantly higher proportions of married respondents in the survey population $(\mathrm{p}<0.001)$ but lower proportions of single $(\mathrm{p}<0.001)$ and divorced/separated people $(\mathrm{p}<0.001)$. Those who reported having a limiting long-standing illness were significantly overrepresented $(\mathrm{p}<0.001)$, as were those who reported that their health was "fair" $(\mathrm{p}<0.001)$, but those who rated their health as "good" or "excellent" were underrepresented. Those in routine and intermediate occupations were significantly overrepresented in the survey population $(\mathrm{p}<0.001)$ while self-employed and routine workers were underrepresented $(\mathrm{p}<0.001)$.

Level of trust and confidence in the healthcare system The mean level of confidence (trust) in today's healthcare system reported by respondents was 6.0 out of a score of 10 , although this declined to 5.6 when respondents were asked about their confidence in the healthcare system of the future. This pattern was borne out in the response to the question: "How much better or worse do you think the general standard of health care in the NHS has been getting in the past 5 years?" 463 (39\%) reported that they felt the standard had deteriorated compared with 249 (21\%) who felt it had improved, and a further 463 (39\%) thought the standard had not changed. $1056(89 \%)$ respondents reported at least a fair amount of confidence (404 (34\%) reported a great deal of confidence) in general practitioners and a similar level of confidence was reported for hospital doctors $(n=1033$ $(87 \%))$ and nurses $(n=1056(89 \%))$. However, the lowest level of confidence was reported for health service managers $(\mathrm{n}=344(29 \%))$ and complementary therapists who were not doctors $(n=463(39 \%))$ although, in the latter case, 309 $(26 \%)$ of respondents reported that they did not know.

\section{Specific aspects of trust}

Table 1 shows that at least $356(30 \%)$ of the respondents reported little or very little trust for most of the items $(n=28)$. The highest levels of distrust were found in relation to the macro level issues of organisation and provision, particularly in relation to waiting times and the consequences for the patient of cost cutting. There were also high levels of distrust in relation to some items involving doctors' professional expertise such as their level of knowledge about a range of diseases.

A different picture emerged from the analysis examining the specific aspects of trust which best predicted generic measures. The dependent variable included in the regression was overall trust rating. The models gave the mean change in overall trust rating per unit lost in the individual determinants. 
Table 3 Sociodemographic determinants of overall rating of trust (confidence)

\begin{tabular}{|c|c|c|c|c|c|}
\hline Determinants & Number & $\begin{array}{l}\text { Crude mean change in } \\
\text { overall trust ratingt }(95 \% \mathrm{Cl})\end{array}$ & $R^{2}$ & $\begin{array}{l}\text { Adjusted * mean change in } \\
\text { overall trust ratingt }(95 \% \mathrm{Cl})\end{array}$ & $\mathrm{p}$ value \\
\hline Age & 1130 & $0.0079(0.001$ to 0.014$)$ & $<0.01$ & $0.0065(-0.003$ to 0.16$)$ & 0.19 \\
\hline \multicolumn{6}{|l|}{$\operatorname{Sex}(M \vee F)$} \\
\hline Female & 651 & & \multirow[t]{2}{*}{$<0.01$} & & \multirow[t]{2}{*}{0.34} \\
\hline Male & 497 & $0.190(-0.41$ to 0.42$)$ & & $0.124(-0.13$ to 0.38$)$ & \\
\hline \multicolumn{6}{|l|}{ Marital status } \\
\hline Single (never married) & 144 & & \multirow[t]{4}{*}{$<0.01$} & & \multirow[t]{4}{*}{0.22} \\
\hline Married or living with long term partner & 827 & $-0.069(-0.42$ to 0.28$)$ & & $-0.280(-0.69$ to 0.13$)$ & \\
\hline Divorced/separated & 84 & $-0.054(-0.58$ to 0.48$)$ & & $0.026(-0.55$ to 0.60$)$ & \\
\hline Widowed & 91 & $0.299(-0.22$ to 0.82$)$ & & $0.035(-0.63$ to 0.70$)$ & \\
\hline \multicolumn{6}{|l|}{ Educational qualifications } \\
\hline Degree & 195 & & \multirow[t]{9}{*}{0.01} & & \multirow[t]{9}{*}{0.32} \\
\hline Teaching or other higher & 42 & $0.841(0.19$ to 1.50$)$ & & $0.805(0.13$ to 1.48$)$ & \\
\hline A level & 116 & $0.151(-0.30$ to 0.60$)$ & & $0.030(-0.45$ to 0.51$)$ & \\
\hline GCSE & 203 & $0.320(-0.07$ to 0.71$)$ & & $0.189(-0.25$ to 0.63$)$ & \\
\hline CSE & 78 & $0.182(-0.33$ to 0.70$)$ & & $0.160(-0.41$ to 0.73$)$ & \\
\hline HND & 36 & $-0.171(-0.87$ to 0.53$)$ & & $-0.387(-0.10$ to 0.32$)$ & \\
\hline GNVQ & 27 & $0.431(-0.36$ to 1.22$)$ & & $0.121(-0.76$ to 1.00$)$ & \\
\hline Other qualification & 128 & $0.090(-0.35$ to 0.53$)$ & & $-0.012(-0.51$ to 0.48$)$ & \\
\hline No educational qualification & 305 & $0.469(0.12$ to 0.82$)$ & & $0.214(-0.25$ to 0.67$)$ & \\
\hline \multicolumn{6}{|l|}{ Ethnic group } \\
\hline White & 1076 & & \multirow[t]{9}{*}{0.01} & & \multirow[t]{9}{*}{0.14} \\
\hline Black Caribbean & 8 & $0.703(-0.66$ to 2.07$)$ & & $1.299(-0.38$ to 2.97$)$ & \\
\hline Black African & 6 & $-0.214(-1.79$ to 1.36$)$ & & $1.012(-0.87$ to 2.89$)$ & \\
\hline Black other black negro & 0 & & & & \\
\hline Indian & 20 & $-0.747(-1.62$ to 0.12$)$ & & $-0.991(-2.00$ to 0.02$)$ & \\
\hline Pakistani & 7 & $-1.333(-0.28$ to 0.13$)$ & & $0.341(-1.84$ to 2.52$)$ & \\
\hline Bangladeshi & 4 & $-2.047(-3.98$ to -0.12$)$ & & $-1.207(-3.86$ to 1.45$)$ & \\
\hline Chinese & 4 & $-2.297(-4.23$ to -0.37$)$ & & $-1.644(-3.81$ to 0.52$)$ & \\
\hline Other & 16 & $-0.297(-1.27$ to 0.67$)$ & & $-0.489(-1.58$ to 0.60$)$ & \\
\hline \multicolumn{6}{|l|}{ Social class/occupation } \\
\hline Higher managerial/professional & 185 & & \multirow[t]{7}{*}{$<0.01$} & & \multirow[t]{7}{*}{0.99} \\
\hline Lower managerial/professional & 297 & $-0.001(-0.36$ to 0.35$)$ & & $-0.002(-0.39$ to 0.38$)$ & \\
\hline Intermediate & 148 & $-0.122(-0.54$ to 0.30$)$ & & $-0.095(-0.57$ to 0.38$)$ & \\
\hline Small employers/own account & 68 & $-0.070(-0.60$ to 0.47$)$ & & $-0.171(-0.76$ to 0.41$)$ & \\
\hline Lower supervisory, craft and related & 113 & $0.044(-0.41$ to 0.50$)$ & & $-0.013(-0.53$ to 0.50$)$ & \\
\hline Semi-routine & 184 & $0.082(-0.31$ to 0.48$)$ & & $-0.054(-0.52$ to 0.41$)$ & \\
\hline Routine & 72 & $0.210(-0.33$ to 0.75$)$ & & $0.053(-0.57$ to 0.67$)$ & \\
\hline \multicolumn{6}{|l|}{ Private health insurance } \\
\hline No & 930 & & \multirow[t]{2}{*}{0.01} & & \multirow[t]{2}{*}{0.03} \\
\hline Yes & 210 & $-0.418(-0.71$ to -0.12$)$ & & $0.338(0.03$ to 0.65$)$ & \\
\hline \multicolumn{6}{|l|}{ Long term illness } \\
\hline Yes & 460 & & \multirow[t]{3}{*}{$<0.01$} & & \multirow[t]{2}{*}{0.38} \\
\hline No & 706 & $0.057(-0.18$ to 0.29$)$ & & $0.139(-0.17$ to 0.45$)$ & \\
\hline Health status over last 12 months & & & & & \\
\hline Excellent & 153 & & 0.01 & & 0.01 \\
\hline Good & 603 & $-0.206(-0.56$ to 0.15$)$ & & $-0.214(-0.58$ to 0.16$)$ & \\
\hline Fair & 317 & $-0.287(-0.67$ to 0.10$)$ & & $-0.385(-0.83$ to 0.06$)$ & \\
\hline Poor & 103 & $-0.511(-1.01$ to -0.01$)$ & & $-0.698(-1.30$ to -0.09$)$ & \\
\hline Don't know & 3 & $-2.905(-5.16$ to -0.65$)$ & & $-3.340(-5.53$ to -1.15$)$ & \\
\hline
\end{tabular}

Table 2 shows the rank order of specific aspects according to their mean change in the generic rating of trust. The pattern of results shows that five of the top 10 strongest determinants were associated with patient centred care, particularly with the doctor-patient relationship (for example, "patients are taken seriously" and "patients get enough attention"). Two items measuring trust with quality of care also came in the top four of the determinants. However, what was notable was the absence from the cluster of strongest determinants of specific items measuring trust in macro level aspects of health care such as waiting times and cost cutting. Three of these items were in the bottom four places.

A similar statistical analysis was carried out using the same dependent variable but with the sociodemographic characteristics of the respondents as the independent variables. The crude results (table 3) show the characteristics examined (age, sex, marital status, educational qualifications, ethnic group, socioeconomic status, private insurance coverage, presence of a limiting long-standing illness, and health status). Age (ageing positively associated with trust), ethnic group (white and black Caribbean positively associated with trust), health status (poor health associated with lower trust), and private insurance coverage (those covered by private health insurance were more likely to report a lower level of trust) were determinants of trust. However, when the demographic variables were adjusted for each other, variation in overall trust is explained by private health insurance coverage and perceived health status.

\section{DISCUSSION}

The evidence from this national cross sectional survey confirmed previous research ${ }^{16}$ that, despite the series of medical scandals, confidence and trust in orthodox medical and healthcare practitioners remains relatively high. This is in marked contrast to the low levels of confidence and trust found in health service managers. This probably reflects the evidence that levels of confidence in the healthcare system now ${ }^{15}$ and in the future were at best modest and expected to deteriorate, and the increased levels of distrust were found for items specifically measuring aspects of 
organisation and finance such as concerns about cost cutting and waiting lists.

Levels of trust overall, however, appeared to be relatively low-at least compared with other indicators of public views such as public satisfaction levels. ${ }^{14}{ }^{18}$ The inadequacies of satisfaction indicators have been well documented ${ }^{14}{ }^{18}$-not least the propensity to underrepresent levels of dissatisfaction-although in this survey the increased levels of distrust might be an artefact of the possible biases in the sample. Older age groups were overrepresented as were those in good health, but the analysis suggested that this might increase levels of trust rather than distrust. Those with limiting longstanding illness (overrepresented in this survey) are sometimes portrayed as "lay experts"19 and may be more aware of the inadequacies and limitations of healthcare provision. However, there was no evidence that those with longstanding illness were more likely to report higher levels of distrust. Clearly, further research is needed to examine the relationship between satisfaction with and trust in health care, although doubts have been raised about the benefits of survey methods, particularly structured postal questionnaires, for eliciting public and user views. ${ }^{18}$ This applies equally to attempts to measure public trust as it does to satisfaction. In addition, there is the possible problem with equating confidence and trust in health care, ${ }^{9}$ and whether the two should be treated as distinct concepts. It has been suggested that trust refers to whether a person is doing a job for his or her benefit as well as the public's, whereas confidence relates to competence to do the job. ${ }^{20}$ However, empirical evidence suggests that the public do not make such a distinction. ${ }^{21}$

Despite the public's expressed concerns about the way the health service is organised and financed, the results of the analysis of the specific determinants of public trust suggest that the most significant dimensions were those measuring the extent to which the doctor is patient centred (that is, behaves professionally and gives patients enough attention) and the perceived level of professional expertise (accurate diagnosis and high quality treatment). This appears to suggest that general assessments of public trust in health care might be replaced by questions about specific dimensions of micro level health care such as professional expertise and the doctor-patient relationship. The analysis seems to suggest that public views about trust tend to match the views of "users" about the quality of health care rather than the broader concerns of "citizens" with how the services are run and paid for. ${ }^{18}$ However, again these findings might reflect the possible biases in the sample with more frequent users, such as those with long-standing illness, being overrepresented.

There was little evidence of variation in the level of trust by social position. The relationship between being covered by private health insurance and lower levels of trust supports other evidence ${ }^{22}$ which suggests that those dissatisfied with

\section{Key messages}

- Despite a series of medical scandals, confidence and trust in orthodox healthcare practitioners remain relatively high.

- Levels of distrust, particularly with how the service is run and financed, are high.

- Key aspects of public assessment of trust were patient centred care and levels of professional expertise.

- Policy makers intent on enhancing public trust should focus on patient centred care.
NHS care-either as a result of direct experience or political beliefs and values (choice, competition)-are more likely to subscribe to private health insurance. However, this relationship between dissatisfaction and the use of private health care is not simple ${ }^{22}$ as people with private health insurance coverage fall into two groups: those who have chosen to subscribe and those such as management executives who have been given it as a company perk. ${ }^{15} 22$ Thus, private health insurance coverage, although on the increase, ${ }^{15}$ is not necessarily a sensitive indicator of a more consumerist or critical orientation to NHS care.

The results of the statistical analysis in this study suggest that the relationship between the perceived performance of the healthcare system at the macro level and the perceived quality of healthcare provision at the micro level is a complicated one. In spite of the higher levels of distrust expressed about the performance of the system, public trust seems to hinge on the performance of the provider in terms of levels of clinical competence and their skills in addressing their patients' needs and interests. Policy makers concerned with maintaining trust and confidence in the NHS need to focus on strategies for enhancing the quality of healthcare provision and on how micro and macro level policies might be integrated to achieve this aim. This is crucial if healthcare professionals are to resist the alleged erosion of trust in experts in general. ${ }^{56}$ However, with the increasing emphasis on managed care and accountability, it might not be practicable to expect to be able to continue to maintain high levels of trust. ${ }^{23}$

\section{ACKNOWLEDGEMENTS}

The authors thank Gwen Coombs for coordinating the survey and the Netherlands Institute for Health Services Research for the use of the trust questions.

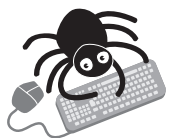

The Confidence in Health Care questionnaire (Appendix 1) is available on the QSHC website at www.qshc.com/supplemental.

\section{Authors' affiliations}

M W Calnan, E Sanford, Department of Social Medicine, University of Bristol, Bristol BS8 2PR, UK

Funding: MRC HSRC.

Competing interests: none declared.

Michael Calnan initiated the study, developed the core ideas, designed the study, supervised the analysis and wrote the paper. Emma Sanford carried out the statistical analysis.

\section{REFERENCES}

1 Allsop J, Saks M. Regulating the health professions. London: Sage, 2002.

2 Salter B. Change in the governance of medicine and the politics of selfregulation. Policy and Politics 1999:27:143-58.

3 Maynard A, Bloor K. Trust and performance management in the medical marketplace. J R Soc Med 2003;96:532-9.

4 Taylor-Gooby PF, Hastie CH. Paying for world class services: a British dilemma. J Soc Policy 2003;32:271-88.

5 Giddens A. Modernity and self-identity. Cambridge: Policy, 1991

6 Beck U. Risk society. London: Sage, 1992.

7 O'Neil O. A question of trust, BBC Reith Lectures 2002. Cambridge: Cambridge University Press, 2002.

8 Putnam RD. Bowling alone: the collapse and revival of American community. New York: Simon and Schuster, 2000.

9 Davies HTO. Falling public trust in health services: implications for accountability. J Health Serv Res Policy 1999;4:193-4.

10 Straten GFM, Friele RD, Groenewegen D. Public trust in Dutch health care. Soc Sci Med 2002:55:227-34.

11 Wendt C. Trust in health care systems. Berl J Soziol 2003;13:371

12 Mechanic D. Changing medical organisation and the erosion of trust. Milbank Quarterly 1996;74:171-89

13 Mechanic $\mathbf{D}$. The functions of limitations of trust in the provision of medical care. J Health Politics Policy Law 1998;23:661-86. 
14 Calnan M Almond S, Smith S. Ageing and public satisfaction with the health service: an analysis of recent trends. Soc Sci Med 2003;57:757-62.

15 Exley S, Jarvis L. Trends in attitudes to health care: 1983 to 2001. London: National Centre for Society Research, 2003

16 MORI. Public retains great trust in doctors MORI Poll, February 2003. http:// www.bma.org.uk/ap.nsf/Content/MORIO3.

17 National Statistics Online. Census 2001. Profiles, England and Wales. www.statistics.gov.uk/census2001/profiles/727-A.asp.

18 Calnan M. The patient's perspective. Int J Technol Assess Health Care $1998 ; 14: 24-31$.
19 Department of Health. The expert patient: a new approach to chronic disease management for the 21 st century. London: Department of Health, 2003.

20 Ravetz J. Public trust in science. Sci Public Aff 2001:18-19.

21 Kent Jennings M. Political trust and the roots of devolution. In: Braithwaite V, Levi $M$, eds. Trust and governance. New York: Russell Sage Foundation, 1998.

22 Calnan M, Cant S, Gabe J. Going private: why people pay for their health care. Buckingham: Open University Press, 1993.

23 Davies HTO, Randall TG. Managing public trust in managed care. Milbank Quarterly 2000;78:609-14.

\section{Clinical Evidence-Call for contributors}

Clinical Evidence is a regularly updated evidence based journal available worldwide both as a paper version and on the internet. Clinical Evidence needs to recruit a number of new contributors. Contributors are health care professionals or epidemiologists with experience in evidence based medicine and the ability to write in a concise and structured way.

\section{Currently, we are interested in finding contributors with an interest in} the following clinical areas:

Altitude sickness; Autism; Basal cell carcinoma; Breast feeding; Carbon monoxide poisoning; Cervical cancer; Cystic fibrosis; Ectopic pregnancy; Grief/bereavement; Halitosis; Hodgkins disease; Infectious mononucleosis (glandular fever); Kidney stones; Malignant melanoma (metastatic); Mesothelioma; Myeloma; Ovarian cyst; Pancreatitis (acute); Pancreatitis (chronic); Polymyalgia rheumatica; Post-partum haemorrhage; Pulmonary embolism; Recurrent miscarriage; Repetitive strain injury; Scoliosis; Seasonal affective disorder; Squint; Systemic lupus erythematosus; Testicular cancer; Varicocele; Viral meningitis; Vitiligo However, we are always looking for others, so do not let this list discourage you.

\section{Being a contributor involves:}

- Appraising the results of literature searches (performed by our Information Specialists) to identify high quality evidence for inclusion in the journal.

- Writing to a highly structured template (about 2000-3000 words), using evidence from selected studies, within 6-8 weeks of receiving the literature search results.

- Working with Clinical Evidence Editors to ensure that the text meets rigorous epidemiological and style standards.

- Updating the text every eight months to incorporate new evidence.

- Expanding the topic to include new questions once every 12-18 months.

If you would like to become a contributor for Clinical Evidence or require more information about what this involves please send your contact details and a copy of your CV, clearly stating the clinical area you are interested in, to Claire Folkes (cfolkes@bmigroup.com).

\section{Call for peer reviewers}

Clinical Evidence also needs to recruit a number of new peer reviewers specifically with an interest in the clinical areas stated above, and also others related to general practice. Peer reviewers are health care professionals or epidemiologists with experience in evidence based medicine. As a peer reviewer you would be asked for your views on the clinical relevance, validity, and accessibility of specific topics within the journal, and their usefulness to the intended audience (international generalists and health care professionals, possibly with limited statistical knowledge). Topics are usually 2000-3000 words in length and we would ask you to review between 2-5 topics per year. The peer review process takes place throughout the year, and our turnaround time for each review is ideally 10-14 days.

If you are interested in becoming a peer reviewer for Clinical Evidence, please complete the peer review questionnaire at www.clinicalevidence.com or contact Claire Folkes(cfolkes@bmigroup.com). 